University of Michigan Law School University of Michigan Law School Scholarship Repository

1915

\title{
The Form of Summons under the Recent Michigan Judicature Act
}

W. Gordon Stoner

University of Michigan Law School

Available at: https://repository.law.umich.edu/articles/1309

Follow this and additional works at: https://repository.law.umich.edu/articles

Part of the Civil Procedure Commons, Legislation Commons, and the State and Local Government Law Commons

\section{Recommended Citation}

Stoner, W. Gordon. "The Form of Summons under the Recent Michigan Judicature Act." Mich. L. Rev. 14 (1915): 135-6.

This Response or Comment is brought to you for free and open access by the Faculty Scholarship at University of Michigan Law School Scholarship Repository. It has been accepted for inclusion in Articles by an authorized administrator of University of Michigan Law School Scholarship Repository. For more information, please contact mlaw.repository@umich.edu. 


\section{Michigan LAW RevieW}

PUBLISHED XFONTRLY DURING THE ACADEMIC YEAR, EXCLUSIVE OF OCTOBER, BY THE LAW FACULTY OF THE UNIVERSITY OF MICHIGAN

\begin{tabular}{|c|c|}
\hline IPTION PRICE \$2.50 PEF & ITS PER \\
\hline $\begin{array}{r}\text { EvaNs H } \\
\text { ADV } \\
\text { VICT }\end{array}$ & $\begin{array}{l}\text { OOK, Editor } \\
\text { BOARD. } \\
\text { I. IAANE }\end{array}$ \\
\hline \multicolumn{2}{|c|}{ Editorial Assistants, appointed by the Faculty from the Class of 1916: } \\
\hline 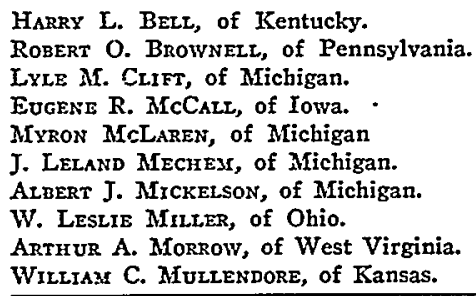 & $\begin{array}{l}\text { RuSSELl H. NEILSON, of Michigan. } \\
\text { HOLLACE M. REID, of Virginia. } \\
\text { ROBERT E. RICIARDSON, of Michigan. } \\
\text { WERNER W. ScrroEDER, of Illinois. } \\
\text { LAWRENCE M. SPRAGUE, of Michigan. } \\
\text { HARRY B. SUITER, of Pennsylvania. } \\
\text { MAURICE WEINBERGER, of Missouri. } \\
\text { THOMAS H. WESTLAKE, of Ohio. } \\
\text { RENVILIE WHEAT, of Michigan. } \\
\text { WALTER F. WHITMAN, of Mlichigan. }\end{array}$ \\
\hline
\end{tabular}

\section{NOTE AND COMMENT.}

The Form of the Summons Under the Recent Michigan. Judicature Acr.-It would be rather remarkable if in revising such a large portion of the statutes as was undertaken by the Commission on Revision and Consolidation of Statutes of the State of Michigan, appointed in I9I3, which reported to the legislature the recently enacted Judicature Act (Public Acts of Michigan, IgI5, § $3 I_{4}$ ), some ambiguity or uncertainty were not to appear in the revision. The Judicature Act is no exception to the general rule, as the lawyer who attempts to begin suit by summons under it will discover at the very outset.

Section 2 of Chapter XIII, of the act provides: "The style of all process from courts of record at law and in chancery in this state shall be 'In the name of the people of the State of Michigan,' and such process shall be tested in the name of the chief justice, or presiding justice or judge, or one of the judges of the court from which the same shall issue, be sealed with the seal of the court, and signed by the clerk thereof, and, before the delivery thereof to any officer to be executed, shall be subscribed with the name of the attorney for the plaintiff and the officer by whom the same shall be isstued ***" 
It will be noted that the section requires the summons to be signed by the clerk and subscribed with the name of the officer by whom the same shall be issued, who would be either the clerk or his deputy. Just what the legislature and the commission intended thereby is not clear. It is barely possible that it was considered desirable to know whether the clerk or his deputy is. sued the summons, and that it was intended to secure such information by this provision. It is more likely, however, that the provision is the result of mistake rather than intention. A mistake in the language of that section of the act dealing with the form of the summons occurred in the revision of 1846 ( $\$$ x, Chap. 97, Rev. Stat. Mich. I846), which rendered the statute uncertain as to whether it required the clerk or other issuing officer, or the plaintiff's attorney, or both, to sign or subscribe the summons. The form of summons prescribed by the court rules remedied the difficulty by requiring the signature of the clerk and the indorsement or subscription of the plaintiff's attorney. It is probable that the proposers and enactors of the recent Judicature Act intended to correct the ambiguity in the former statute by the section quoted, and this would have been accomplished had the words "and the officer by whom the same shall be issued," which conclude that portion quoted above, been omitted. This conclusion is strengthened by a note appended to the said section in the Commission's report (p. 93 of report), which indicates that the intent was to merge in this section the contents of the section of the old statute ( $\$ 9984$, Mich. Comp. Law I897), which dealt with the form of process and of a portion of the sections ( $\$ \S$ 452 and 453, Mich. Comp. Laws, I897) dealing with the chancery subpoena, none of which required the clerk to sign the process twice. The new statute as it stands requires too much, i. e., two signatures of the clerk instead of one.

As indicated above the ambiguity in the old statute was remedied by the court rules ( $\$ c$, Circuit Court Rule I). The court will remove the difficulty pointed out in the new act by the same means. If the court in the rules should provide the same form of summons as is at present required thereby, a nice question might be raised as to the court's power to make sufficient a summons not containing some of the statutory requirements. As such a question, if it did arise, would be finally decided by the tribunal upon which devolves the duty of prescribing the rules, the decision would undoubtedly uphold the form of summons prescribed by the rules.

G. S. 